\title{
Does Accounting Matter? A Social Constructivist Perspective
}

\author{
Krista Loewen ${ }^{*}$
}

\begin{abstract}
Accounting plays an integral role in the construction of economic reality, and therefore, it matters to accountants, users of financial information, and all those who are impacted by the decisions made based on accounting information. Beyond examining why accounting matters, this paper demonstrates how a cyclical process creates and reinforces a particular accountant-created reality, and how legitimacy is gained for agents within the system. Accounting matters because as the preparers of financial statements, accountants construct a reality. As this constructed reality is used, it is legitimized and perpetuated, and the process repeats to reinforce the reality and influence society. Throughout this process, the structure of society is also reinforced. Understanding that the reality is a created one means that societal change is possible, as the construction can be altered.
\end{abstract}

Keywords: legitimacy theory; accounting theory; social constructivist perspective; power of accountants

\section{Does Accounting Matter?}

Accountants are often thought of as 'bean counters,' uninteresting paper-pushers who merely record a reality that already exists. Under this assumption, it is easy to question whether accounting matters - do we really need this recording function to codify something that exists on its own? However, it will be demonstrated that accountants create a reality that does not entirely exist otherwise. Of course, it seems obvious for an accounting student to reaffirm that accounting matters. More important than simply deciding if accounting matters, is examining why and how accounting is significant. Accountants construct a reality to make sense of the world and the numbers they are given. As the created reality is used by various groups to further make sense of the world, the reality is reinforced and validated in a cyclical process. Accounting matters to accountants, users of financial results, and society, because it plays an integral role in the construction of reality. The results of accounting are taken and used to make decisions, which creates and perpetuates the reality that effects people, businesses, and the world.

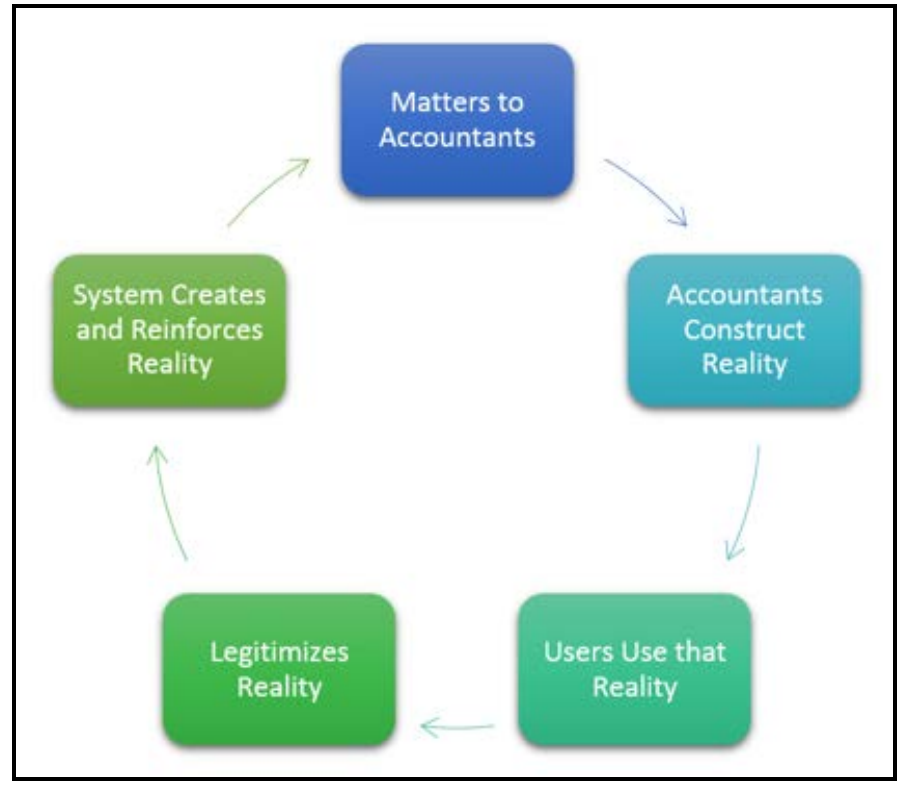

Figure 1. A depiction of the logical flow of this paper and the arguments within it. The diagram is included to increase understanding and provide a visual representation of the process by which accounting is used to construct and reinforce reality.

\footnotetext{
*Edwards School of Business, Accounting, Bachelor of Commerce Correspondence: loewenkrista@gmail.com
} 


\section{Accounting Matters to Accountants}

Accounting is a process of gathering, categorizing, and manipulating financial information for users (Rochester Institute of Technology, 2012). Accountants need the process of accounting so they can prepare financial statements to communicate the economic, social, and environmental reality of an organization to internal and external users. In this common view, accounting is merely capturing and reporting a concrete and pre-existing reality. Accountants take what the company owns and owes, the results and impacts of its operations - and filter this information into financial reports that aim to present the reality of that organization.

The principle of linguistic relativity and the SapirWhorf hypothesis posit that different languages actually make their speakers' subjective experiences of the world markedly different (Smilek, Sinnet, \& Kingstone, 2013). In an accounting context, this means that accountants think and use information in a different way than nonaccountants, and communicate reality in a way only they will understand. Their experience of reality is also different, and in communicating their specific reality, they also play a role in creating that unique reality for others to utilize. For example, "[a]ccounting method elections can have direct impact [on] earnings" (Hu, Liu, \& Miller, 2013, p. 13), so the way accountants understand and think about reality, which is influenced by their language of accounting, impacts earnings and the way users perceive a particular company. A seemingly concrete reality requires policy choices and is subject to this different accounting language, and as a result the accounting reality is variable. This demonstrates that accounting is beyond just a function of capturing and recording; accountants also play a role in a construction of a certain reality.

Critics may argue that of course accounting matters to accountants because they create and perpetuate the function of accounting in order to continue to have a profession (The Economist, 2014i Deegan \& Unerman, 2011; Gomes, Carnegie, Napier, Parker, \& West, 2011). As Hines (1988, p. 258) wrote, "social power accrues to those who can influence conceptions of reality," which is the case for accountants, who can use the power they are given to perpetuate that power. But accounting also matters to people far beyond the accountants that create a certain reality.

\section{Accountants Construct Reality and Reinforce the Structure of Society}

The assumption that accounting is a "reflection of an underlying reality... [is] highly problematic" (Deegan \&
Unerman, 2011, p. 539; Epstein \& Henderson, 2011). Instead, accountants shape that very reality they are charged with communicating to various stakeholders. This works for two primary reasons, first, the problem that "economic reality is not some singular, peculiar feature of society" (Salvary, 1997, p. 71), but rather a dynamic conception of reality that can change based on varying perspectives. It depends on what is important to the organization, and what types of information are available and relevant (Salvary, 1997). As Pava (2010) put it, "[o]ur concepts structure what we perceive" (Pava, 2010, p. 3). A second aspect of the reason accountants do not merely objectively represent reality (Mouck, 2004) is because of the inherent subjectivity in their work and daily decisions (Deegan \& Unerman, 2011). Accountants are expected to faithfully represent reality (Deegan \& Unerman, 2011), but the decision of what is faithful representation is laden with judgements. For example, researchers have explored how there are different ways to account for the same transaction, such as that accounting decisions vary based on a principles or rules-based accountant as well as auditor (Jamal \& Tan, 2010). After transactions are interpreted, this progresses towards reality in a paper by Entwistle \& Bastiaansen (2015), which shows how differently the priceearnings ratio, a seemingly objective number based on outwardly objective accounting information, is really constructed in various ways based on objectives, current events, and available information. These two examples demonstrate that accounting numbers and reports contain subjectivity, from the countless judgements made when creating those reports (Deegan \& Unerman, 2011) and from an expectedly imperfect representation of an ever-changing reality (Salvary, 1997). This dynamic reality, which has been constructed in many steps, is then used to make decisions, which reinforces the reality and changes the fabric of society.

The opportunity of subjective accounting means reports present a biased view of reality for the unaware user (Deegan \& Unerman, 2011; Young, 2006), who may or may not realize the judgements that went into the representation. Reality can be contradictory and complex, and accountants take the mass of information they are given and carefully assemble it, but in this they are able to select what additional disclosures to make (Deegan \& Unerman, 2011), creating a new reality for users (Hines, 1988). As "people think and act on the basis of [the] picture" (Hines, 1988, p. 254), they give accountants power to shape their decisions, for better or for worse. The process, creating financial reports based on judgements and presenting them so users can make decisions, reinforces the structure of society. Inequality builds - companies who can afford to hire the accountants who will present the best "reality" of their operations will flourish, and those who cannot will fall behind (Deegan \& Unerman, 2011). 
Individuals with the resources, be they knowledge or the ability to consult someone with knowledge, can assess and understand the subjectivity of the reality accountants create and make more informed decisions. Those individuals who do not may make less effective decisions and therefore, have worse outcomes, so inequality is reinforced and exacerbated.

Critics of this social constructivist perspective might argue that accountants merely communicate reality (Hines, 1988), and that efficient markets can see through accounting to the true underlying economic reality (Gomes et al., 2011; Epstein \& Henderson, 2011). If this efficient market were the case, investors could go beyond accounting to cash flows (Deegan \& Unerman, 2011), and accounting would not matter (Hines, 1988). Cash flows are considered more persistent than accounting numbers, as accounting incorporates accruals such as depreciation or provisions for warranty claims, but cash flows are more concrete. They are the amounts the company actually spent or earned; they are already "real." When analyzing investments, cash flows are sought to find the best opportunities, because this persistence indicates that a company will continue to be successful over time. The efficient market hypothesis says that the market reacts quickly to new information, and incorporates it rapidly into the stock price (Deegan \& Unerman, 2011). While partially true, this simplified model does not encompass the entire situation. The assumption that markets are efficient does hold on average, but there are many anomalies and situations where it does not (Deegan \& Unerman, 2011). These anomalies are where accountants have the opportunity to influence the reality that is created, which users then rely upon. Users are irrational and sometimes make irrational decisions based on the information they are given, marred by biases and human inconsistencies (Deegan \& Unerman, 2011; Aronson, Wilson, Fehr, \& Akert, 2013; Young, 2006). Accounting is so much more than just a "market practice guided by equilibrium in an efficient market" (Hopper, Annisette, Dastoor, Uddin, \& Wickramasinghe, 1995, p. 528); rather, it is "a social practice within political struggles" (Hopper et al., 1995, p. 528). "[l]n communicating reality, [accountants] construct reality" (Hines, 1988, p. 257), a carefully chosen reality that reinforces the existing structure of society, increasing inequality.

\section{Users Employ Accountants' Reality to Make Decisions and Take Action}

Accountants, with their inherent biases and judgements, decide what characteristics are important in a company and should be reported or emphasized (Deegan \& Unerman, 2011). The results that accountants report are used to make decisions such as whether organizations are worthy of credit, investment, or legitimacy (Deegan \& Unerman, 2011). For instance, in 2016 Potash Corp made the difficult decision to suspend the mines near Sussex, New Brunswick, as it had the highest costs of any of its plants (McGugan, 2016). Four hundred and thirty jobs were lost in the community of 4,300 people (Statistics Canada, 2011; McGugan, 2016), leaving a devastating impact in its wake. How would the cost of these operations have been determined? Executives had to look at the information they were given, carefully compiled and filtered by accountants, and use those accounting results to make a decision. As decisions are made based on accounting results, the reality is reinforced and validated, increasing in strength. Accounting reports become reality because they are "real in their consequences" (Hines, 1988, p. 257). When people use accounting results, they provide continuing proof of reality as the basis of accounting, confirming the validity of that conception of reality, and making it actual reality (Deegan \& Unerman, 2011; Hines, 1988).

In contrast to the perspective of using a constructed version of reality from accountants, some may argue that users are just using 'real' reality. The most simplistic view of accounting is that it functions merely to portray what is, and that there are no judgements involved in that portrayal. Reality is dynamic, and it is extremely difficult to depict a complex 'actual' reality without introducing any biases or judgements. In addition, there is much evidence for the power of disclosure in shaping decisions and perceptions (Deegan \& Unerman, 2011). For example, behavioral research studies how users of accounting react to various disclosures, forms, and contexts, and how these impact decisions differently (Deegan \& Unerman, 2011; Frederickson \& Miller, 2004). Because this is the case, accounting cannot merely be depicting the true reality; it must be depicting some carefully chosen version of that true reality. Otherwise, reactions would be much more consistent, because they would be based on the true reality. Accounting results are based in reality, but there is no single representation that is right and all the others wrong. There are countless user groups directly and indirectly impacted by these judgement-laden and constructed accounting results, including investors, managers, the corporations themselves, and various members of society, which will be discussed to demonstrate why accounting truly matters. As these groups make decisions based on accounting results, the reality accountants have created is reinforced, and accounting continues to matter.

\section{Investors and Creditors}

The conceptual frameworks of accounting are the overall principles to be used when creating accounting standards and when preparing financial reports. Conceptual 
frameworks underlie the creation of standards and reports, and they focus on investors and creditors as the primary users of financial information (Young, 2006). Other readers are considered "like investors and creditors and would thereby require similar information" (Young, 2006, p. 590). It is also assumed that they want information to aid in predicting future cash flows (Young, 2006; Deegan \& Unerman, 2011). Although investors and creditors are not the only meaningful users of accounting information, they are primary ones. Young (2006) discusses how investors, often assumed to be informed and discerning, are actually irrational, inconsistent, and relatively uneducated. Users are often not knowledgeable and do not know what information they need (Young, 2006). An efficient market argument would require users to be rational profitmaximizers who can see through accounting accruals and choices to cash flows (Deegan \& Unerman, 2011), but if investors are actually irrational (Young, 2006), it is more evidence for the idea that accounting matters because users rely on it despite market forces. Investors and creditors rely on accountants' depictions of reality to make their decisions, reinforcing the reality accountants have created.

Through financial statements, accounting provides a basis for many business decisions (Young, 2006; Rochester Institute of Technology, 2012). It impacts investors because the choices accountants make influence investors' often irrational decisions. For example, a potential investor or creditor may use financial statements, prepared by accountants, to decide whether or not to invest or lend funds to a company. However, trusting the profession of accounting, and being limited in their rational ability to seek and consider every possible piece of information, that investor or creditor may not fully explore the 'real' reality of the company in consideration. As a result, a suboptimal resource allocation decision may be made, choosing a company that is merely presenting its reality in the best light. The company may then take the funds gained, invest them in a project, and make more profits than the company that could not secure financing. That same company now has more resources to continue to present their reality positively and secure increasing financing. This demonstrates how the cycle perpetuates itself - accountants create a reality, which investors and creditors use to make decisions, and the reality is reinforced by the results of those decisions.

\section{Managers}

While investors and creditors are typically thought of as the primary users of the results of accounting (Young, 2006; Deegan \& Unerman, 2011), other important users should not be overlooked. Managers use accounting nearly every day, whether it is in preparing reports or in choosing from alternatives that have differing accounting implications. Accounting matters to them because it impacts their compensation, job security, and performance evaluation. The various ways managers and accountants depict the company's operations impacts net income, which is often linked to compensation in the form of bonuses or job security (Deegan \& Unerman, 2011). As a result, managers are motivated to use various earnings management strategies, such as profit maximizing or taking a bath (intentionally reducing net income to preserve bonus potential for the next year), depending on the situation (Deegan \& Unerman, 2011). Managers use accounting information to "plan and control" (Young, 2006, p. 581) the organization's activities, and they are then evaluated based on the results of those activities. Accounting is a way to communicate the results of the company, but it is also a way to create a certain reality that managers find most beneficial. Managers are both users and creators of accounting results; therefore, they have a role in making decisions and in portraying the results, and in both roles, they create and reinforce reality through accounting.

\section{Companies}

Taking a broader view of the impacts of accounting, companies as a whole are also affected by accounting results, therefore accounting matters to them and to whether they succeed. "[A]ccounting imposes a conceptual boundary" (Hines, 1988, p. 258) around an organization, and these boundaries are needed for a social construction of the organization, a reality. They also impact the organization, the way it is defined changes the results it portrays to the public, impacting public perceptions of that company and determining whether it gains resources like legitimacy or financing (Deegan \& Unerman, 2011). Accounting is a way to legitimize the "social and political structure of the organisation" (Carpenter \& Feroz, 1992, p. $618)$, making users believe accounting results are legitimate and objectively true despite their subjectivity (Carpenter \& Feroz, 1992). In trying to influence the boundaries of accounting and gain legitimacy, companies simultaneously affect and are affected by the structures of accounting, reinforcing the accounting reality.

\section{Regulators and Governments}

Regulators and governments are also influenced by accounting. Like many groups, they seek legitimacy from the public through being perceived as fulfilling the social contract (Deegan \& Unerman, 2011). This often comes in the form of attempting to protect the public from the selfinterested individuals behind corporations (Deegan \& Unerman, 2011). It has been well-established that stock markets are shaped by sentiment - the level of confidence users have in the markets and particular companies determines stock prices, and also drives performance of the 
market overall (Barberis, Schleifer, \& Vishny, 1998; Baker \& Wurgler, 2007). Regulators aim to ensure investors have confidence in capital markets to ensure the success of these markets, which enables the capitalist society which underpins it all to continue.

If regulators and governments are perceived as failing at promoting the public interest, they lose legitimacy and fall out of political favor. Therefore, they have an interest in ensuring accounting is successful at portraying seemingly accurate results that users will trust as a base for their decisions, so they help ensure the accountants' reality is perceived as legitimate. In addition, "[a]ccounting standards are not a mirror for some users' realities... but instead they contribute to constructing a particular viewpoint about what financial statement users should be like" (Young, 2006, p. 594). Accountants play a key role in constructing standards (Deegan \& Unerman, 2011; Financial Reporting \& Assurance Standards (anada, 2016), and as a result they can work to create and perpetuate a reality that they find beneficial through regulators and governments. Accounting matters to regulators and governments because as they make decisions, with the aim of maintaining or increasing their legitimacy, they perpetuate the reality of accountants for themselves and for other users.

\section{Society}

Accounting impacts many facets of society, but aside from groups already mentioned, it especially affects economies and the environment. First, accounting drives economies by preparing information for a wide range of users so they can make investment or other decisions. While accounting results are often taken as objective and judgement-free numbers, many subjectivities underlie the reality accountants portray. When accounting fails to depict the true operations of a company, not only is that company at risk, so is the entire economic system that relies on those accounting results. When accounting indicates a company is doing well, people buy that stock or lend it money, allowing the company to grow, causing economic growth while reinforcing the structure of society. What accountants do matters, and it impacts systems as broad and whole economies. As participants make decisions based on accounting reality, it becomes even more real, and the accounting reality continues to matter.

When accountants determine profits of an organization, they "ignore many social and environmental externalities caused by the business" (Deegan \& Unerman, 2011, p. 538). If particular costs are not recognized, those costs will also not be realized (Hines, 1988), and they will not become part of the reality users see. For example, the accountant at an oil refinery will probably not be motivated to quantify the magnitude of the environmental impacts of the company; therefore, users will not have a seemingly objective number to attach to the issue, and they will consider it secondary in their decisions. The reality of users omits this important information, and the environment will continue to be harmed with minimal consequences to the company doing the harming. Although the environment is not a physical 'user' of accounting, it is often damaged as a result of the decisions of various users based on imperfect accounting information, who perpetuate the reality of accounting through their decisions. Users are a diverse and dynamic group, which, rational or not, use accounting reports to make decisions, validating and reinforcing the reality that was presented to them by accountants.

\section{Accounting Legitimizes Reality and Itself}

So far, it has been demonstrated that in communicating reality, accounting creates reality. Then, by delving deeper into specific groups who impact and are impacted by accounting, several of the ways this reality is perpetuated have been shown. The next logical step is to examine how accounting legitimizes the reality it creates, in turn legitimizing the profession of accounting. Legitimacy is achieved through symbolic or substantive means, meaning either by saying change has occurred or by actually creating change (Deegan \& Unerman, 2011; Masrani \& McKiernan, 2011). A legitimacy gap occurs when the expectations of society do not line up with the actions of a particular group, in this case, accountants (Deegan \& Unerman, 2011). To close this legitimacy gap, groups tend toward symbolic measures to appear to be fulfilling the social contract, allowing them to maintain legitimacy and continue operation (Masrani \& McKiernan, 2011). For example, the conceptual frameworks made by accounting standard setting boards, which are largely comprised of accountants, legitimize the accounting profession and financial reports in two ways (Deegan \& Unerman, 2011; Financial Reporting \& Assurance Standards Canada, 2016). Conceptual frameworks are the basic underlying principles (such as the definition of what an asset is) used when creating accounting standards, which are intended to help in standard setting as well as interpretation (IFRS, 2016). They reproduce assumptions of an objective world, even though objectivity is extremely rare (Deegan \& Unerman, 2011). Not only that, they create an alleged 'basis' for accounting standards so those standards, and the profession, seem legitimate (Deegan \& Unerman, 2011) to users who rely on accounting results. Furthermore, the legitimacy of the accounting profession brings legitimacy to the reality created by the profession - the specific accounting reports they choose to release (Masrani \& McKiernan, 2011). Through disclosures, press releases, conceptual frameworks, and similar means, accounting results can appear more legitimate (Masrani \& McKiernan, 2011) through the profession telling users how legitimate it is. By 
creating a reality, and making people believe in that reality through disclosure, the reality is legitimized, subsequently bringing even more legitimacy to the accounting profession.

Substantive methods could also be used to legitimize the accounting profession and accounting results. There are alternatives for what is presented, and the closer this presented reality is to actual reality, the more legitimate accounting becomes in a concrete and substantive way. Users are able to place more reliance on accounting results as a true representation of reality because the long-term outcomes are consistent with what was expected based on interpretations of those accounting results. Barriers to substantive change, however, include the fact that accounting inherently involves judgement, and that the companies and individuals hiring accountants want to be portrayed as positively as possible. There are further constraints in terms of efficiency - sometimes unraveling the underlying reality is challenging and takes extensive work from accountants, extra work for which neither clients nor firms want to incur higher costs. Practical concerns, including how to quantify and audit the impacts of externalities such as environmental impacts, also impede presenting true reality. While substantive approaches to achieving legitimacy are more sustainable than symbolic means, the challenges to execution are much greater, and therefore the symbolic approach is often favored.

Some might argue that accounting is not legitimate (The Economist, 2014), and neither is the accounting reality. Many who have lost faith in the profession contend that accountants have become "dozy watchdogs" that are "dodgy" (The Economist, 2014) and lack competence. While accounting is flawed, and people rely on the reality created by accountants anyways, it is nonetheless legitimized and becomes even more real. So while accounting and accounting results may face a legitimacy crisis, it remains true that people rely on accounting every day, and continue to despite the many accounting scandals that make the news, and the even more that do not (Nisbett \& Sheikh, 2007). Overall, this demonstrates that while the legitimacy may sometimes be questioned, the accounting profession has been very successful at legitimizing itself, as well as legitimizing the reality it creates.

\section{This System Reinforces Reality and Inequality}

As a whole, the system of accounting, and how it matters to various users, creates its own legitimacy, which then reinforces and creates reality. "[E]conomic reality does not exist independently of the accounting practices that communicate [and construct] that reality" (Mouck, 2004, p.
526). Furthermore, "the practice of accounting tends to support particular economic and social structures, and reinforces unequal distributions of power and wealth across society" (Deegan \& Unerman, 2011, p. 517). Accounting is not neutral or unbiased (Mouck, 2004), but rather it maintains the inequality and structure of society, "sustaining privileged positions of those in control of particular resources while undermining... those without capital" (Deegan \& Unerman, 2011, p. 518). What this entails is that "the outcomes of accounting policy are essentially political in that they operate for the benefit of some groups in society and to the detriment of others" (Cooper \& Sherer, 1984, p. 208). Accountants create a reality, and as that reality is used to make decisions, it is reinforced, and the reality is no longer merely an accountant-created one, it is also a system-created one. Essentially accountants have made a reality to make sense of the world, and then people have used that created reality to further make sense of the world, validating and reinforcing the reality at every step of the process.

Even the conception of users is made up by standards setters (Young, 2006), but it is nonetheless used to create standards and guide the practice of accounting (Deegan \& Unerman, 2011). As this notion of users guides behavior, it reproduces itself, and continues to be ingrained into a wholly-constructed system. So why, then, do people trust these created realities, just to have a world that makes some sense, if it is not always based in fact? The answer is simple, and it is that humans need the world to have order and make sense, and will go to great lengths to ensure it does (Smilek et al., 2013). Consciously or unconsciously, biases build (Aronson et al., 2013), and users rely on the reality accountants have created because it is there, it is needed, and it seems relatively legitimate.

Critics might argue that this view of the system as reinforcing reality and social inequality is too pessimistic (Deegan \& Unerman, 2011), that social inequality is inevitable and accounting is not solely responsible for it. While accounting may not be the only perpetrator of this inequality, it is a crucial one (Deegan \& Unerman, 2011), as demonstrated throughout this paper, and should be treated as such. In addition, rather than it being pessimistic, this paper is realistic in showing the many ways accounting reinforces and constructs reality as it is currently known, reinforcing inequalities in society. Others might claim that accounting is a valuable system and should not be questioned, but whether it is valuable is not the key focus. Rather, the focus is on being aware that accounting creates a reality (Mouck, 2004), which is reinforced in various ways, creating legitimacy for that reality and for the profession, and understanding that it does construct a reality which is relied upon and has countless impacts on people's lives.

Perhaps a different reality could be presented, one that leads to less inequality, improving not only the system 
that presents accounting results but also the impacts of those results. The obstacles to this change, however, are vast and deeply ingrained. As explored earlier, some of these barriers include lack of efficiency in uncovering true reality, economic incentives, inherent judgement, and other practical constraints. When attempting to change the underlying sociopolitical system, there are further difficulties that arise from philosophical differences. Politically, for instance, a laissez-faire approach to the accounting system would favor allowing market forces to handle the inequality, encouraging regulators not to intervene. A collectivist perspective would encourage intervention, but this action would still be hindered by the more practical barriers discussed previously. Overcoming the practical barriers requires philosophical agreement on how to overcome them. Ultimately, however, the reality that is presented is inextricably linked to the systems and people creating it, and there are major impediments to reducing inequality by approaching this creation of reality differently.

\section{Discussion and Conclusion}

\section{Relevance}

Explaining how accountants are able to create, legitimize, and construct reality is important to the fields of accounting practice and theory. It is necessary to consider the impacts in a practical and academic setting so that reliance on outcomes can be adjusted accordingly. More specifically, awareness is necessary so users and accountants can understand the biases and judgements that entered into the reality, rather than believing accounting is merely objective (Mouck, 2004; Entwistle \& Bastiaansen, 2015), so appropriate conservatism and care can be exercised. The way accounting is able to create reality matters to so many users, as discussed previously, and to broader society, because it affects their decisions and as a result, affects their lives.

The system of accounting could be improved by shifting focus from symbolic to substantive means of achieving legitimacy. While there are significant barriers to this, the long-term benefit is increased sustainability of the profession and the entire system. Accountants within the system are already working towards creating change in substantive ways. For example, standards continue to be updated with the intent of improving consistency, simplicity, and clarity for users (CPA Canada, 2016). Understanding that the accounting reality is created and shaped, as shown throughout this paper, highlights the importance of not accepting the existing inequality or merely achieving legitimacy in symbolic ways. Substantive change is needed to fundamentally improve the system and enable continued reliance on accounting results.
Another common theme throughout this paper is that users are not necessarily the "rational economic decision-makers" (Young, 2006, p. 591) they were thought to be. If standards are based on one construction of users, and practice is based on another, standards are less effective and results and disclosures are less useful than they could be. The information provided to users impacts their decisions (Young, 2006), and accounting creates a reality which is catered to a certain conception of the user. So a way to improve accounting and the reality it creates could be by understanding users better (Young, 2006). This highlights another reason why this paper is relevant to the field of accounting - if the process of accounting and its creation of reality is understood, there are more ways to improve it.

While some, especially proponents of the efficient market hypothesis might argue that accounting does not matter because the underlying economic reality can be derived by users independent of the function of accounting. However, it has been shown that accounting matters to many different user groups, as the function impacts perceptions and decisions. Accounting is not merely an objective process of communicating results, but rather a process filled with subjectivity in creating a reality influenced by incentives and opportunities. What accountants do matters. It is not merely an irrelevant representation of a company that only managers look at or care about. Other users make decisions based on accounting results, so it matters how that accounting was done, and the reality created in the process matters to those users.

\section{Conclusion}

Overall, this paper aims to remind readers "that the reality we experience today might easily have been different" (Young, 2006, p. 581). Understanding this process allows us to question the institutions that created our current system (Young, 2006; Entwistle \& Bastiaansen, 2015), rather than just taking them for granted. Accounting results, the structure of society, and the actors that have legitimacy are not fixed, but are created in the system. Furthermore, it helps us recognize that "[s]ocial welfare is likely to be improved if accounting practices are recognized as being consistently partial, that the strategic outcomes of accounting practices consistently (if not invariably) favour specific interests in society and disadvantage others" (Cooper \& Sherer, 1984, p. 208). Knowing this should not discourage us, but rather empower us to consider how the system can be shaped and molded to improve society.

This paper has shown that accounting matters to accountants and various users because it has a major role in the construction of reality. Accounting matters to accountants because it influences the work they do and whether they perpetuate the power structures of society. 
Rather than merely communicating reality, accountants create a reality that is most beneficial, which users rely on to make decisions. As decisions are made based on accounting results, investors and creditors, managers, companies, regulators, and society all impact and are impacted by accounting. The users that make varying decisions with accounting information further reinforce and validate the reality as created by accountants. Because so many decisions are made based on accounting reports, accounting gains legitimacy, alongside creating its own legitimacy. Accountants act to legitimize the reality they create and the profession, perpetuating a system that reinforces and creates a desired reality while increasing inequality. So does accounting matter? Of course it does, the reality it creates matters to all the people at work in this process, and to all the people affected by the outcomes of the process.

\section{Acknowledgements}

A huge thank you to Kenneth Fox for the many comments and discussions, for encouraging me to write and never stop learning. Also, thank you to Michael Bazin, Suresh Kalagnanam, Gabby Gill, and the reviewers who provided comments and helped refine and expand my ideas.

\section{References}

Aronson, E., Wilson, T. D., Fehr, B., \& Akert, R. M. (2013). Social psychology (5th Canadian ed.). Don Mills, ON: Pearson Canada Inc.

Baker, M., \& Wurgler, J. (2007). Investor sentiment in the stock market. Journal of Economic Perspectives, 21(2), 129-151.

Barberis, N., Schleifer, A., \& Vishny, R. (1998). A model of investor sentiment. Journal of Financial Economics, 49, 307-343.

Carpenter, V., \& Feroz, E. (1992). GAAP as a symbol of legitimacy: New York State's decision to adopt generally accepted accounting principles. Accounting, Organizations and Society, 17(7), 613643.

Cooper, D. J., \& Sherer, M. J. (1984). The value of corporate accounting reports: Arguments for a political economy of accounting. Accounting, Organizations and Society, 9(3/4), 207-232.
CPA Canada. (2016). Standards digest: accounting and auditing standard-setting in Canada - June/July 2016. Retrieved from Chartered Professional Accountants Canada: https://www.cpacanada.ca/en/connecting-andnews/cpa-magazine/articles/2016/june/standardsdigest-accounting-and-auditing-standard-settingin-canada-june-july-2016

Deegan, C., \& Unerman, J. (2011). Financial Accounting Theory (2nd European ed.). Maidenhead, Berkshire, England: McGraw-Hill Education (UK).

Entwistle, G., \& Bastiaansen, I. (2015). Variations in P/E. Strategic Finance, 48-53. Retrieved from http://sfmagazine.com/post-entry/october-2015variations-in-pe/

Epstein, R. A., \& Henderson, M. T. (2011). Do accounting rules matter? The dangerous allure of mark to market. Journal of Corporation Law, 36(3), 513549 .

Financial Reporting \& Assurance Standards Canada. (2016). Accounting Standards Board. Retrieved from http://www.frascanada.ca/accounting-standardsboard/members/acsb/index.aspx

Frederickson, J. R., \& Miller, J. S. (2004). The effects of pro forma earnings disclosures on analysts' and nonprofessional investors' equity valuation judgements. The Accounting Review, 79(3), 667686.

Gomes, D., Carnegie, G. D., Napier, C. J., Parker, L. D., \& West, B. (2011). Does accounting history matter? Accounting History, 16(4), 389-402. doi:10.1177/1032373211417993

Hines, R. D. (1988). Financial accounting: In communicating reality, we construct reality. Accounting Organizations and Society, 13(3), 251-261.

Hopper, T., Annisette, M., Dastoor, N., Uddin, S., \& Wickramasinghe, D. (1995). Some challenges and alternatives to positive accounting research. (S. Jones, C. Romano, \& J. Ratnatunga, Eds.) Accounting Theory: A Contemporary Review.

Hu, N., Liu, L., \& Miller, W. F. (2013). The path to reporting economic reality - Why all CEOs should have accounting degrees. Journal of Management Policy and Practice, 12(2), 11-18. 
IFRS. (2016). Conceptual Framework. Retrieved from International Financial Reporting Standards: http://www.ifrs.org/Current-Projects/IASBProjects/Conceptual-

Framework/Pages/Conceptual-FrameworkSummary.aspx

Jamal, K., \& Tan, H.-T. (2010). Joint effects of principlesbased versus rules-based standards and auditor type in constraining financial managers' aggressive reportin. The Accounting Review, 85(4), 1325-1346.

Masrani, S., \& McKiernan, P. (2011). Accounting as a legitimising device in voluntary price agreements: The Dundee jute industry. Critical Perspectives on Accounting, 22(4), 415-433. doi:10.1016/j.cpa.2011.02.001

McGugan, I. (2016, January 9). Potash Corp. closes N.B. mine as prices plummet, stock falls. Retrieved from The Globe and Mail: http://www.theglobeandmail.com/report-onbusiness/industry-news/energy-andresources/potash-corp-to-suspend-newbrunswick-operations-cut-more-than-400jobs/article28253993/

Mouck, T. (2004). Institutional reality, financial reporting and the rules of the game. Accounting, Organizations and Society, 29(6), 525-541.

Nisbett, A. V., \& Sheikh, A. (2007). Accounting scandals: Does "rules vs. principles" matter? Tennessee CPA Journal, 10-12. Retrieved from http://www.drlillie.com/a574/articles/acct_scandals . .pdf

Pava, M. L. (2010). Teaching accounting ethics: A thought experiment. Working Paper.

Rochester Institute of Technology. (2012, January 3). What is accounting? Retrieved from Saunders School of Business: http://saunders.rit.edu/programs/undergraduate/a ccounting/what-is.php

Salvary, S. C. (1997). Some conceptions and misconceptions on reality and assumptions in financial accounting. Journal of Applied Business Research, 13(1), 69-81.

Smilek, D., Sinnet, S., \& Kingstone, A. (2013). Cognition (5 ed.). Don Mills, Ontario: Oxford University Press.
Statistics Canada. (2011). Census Profile. Retrieved from https://en.wikipedia.org/wiki/Sussex, New Bruns wick

The Economist. (2014, December 13). The dozy watchdogs. Retrieved from The Economist: http://www.economist.com/news/briefing/2163597 8-some-13-years-after-enron-auditors-still-cantstop-managers-cooking-books-time-some

Young, J. J. (2006). Making up users. Accounting, Organizations and Society, 31(6), 579-600. 
